\title{
Contributions from the Autonomous University of Zacatecas in the Epidemiology, Diagnosis and Treatment of Trichinellosis, 1986-2021
}

\author{
Moreno García $\mathrm{MA}^{1 *}$, Muñoz Moreno $\mathrm{CY}^{2}$, Chávez Guajardo EG ${ }^{3}$, Maldonado Tapia $\mathrm{HM}^{1}$, Vargas \\ Rodríguez $\mathrm{MR}^{1}$, Sánchez Marrufo $\mathrm{D}^{1}$, Crespo Jiménez $\mathrm{E}^{1}$ and Muñoz Escobedo $\mathrm{JJ}^{3}$ \\ ${ }^{1}$ Unidad Acadèmica de Ciencias Biológicas, Mexico \\ ${ }^{2}$ Universidad de Groningen, Netherlands \\ ${ }^{3}$ Unidad Academica de Odontologia, Mexico
}

*Corresponding author: Moreno García MA, Unidad Acadèmica de Ciencias Biológicas, Mexico

\section{ARTICLE INFO}

Received: 幽 October 18, 2021

Published: 慧 October 25, 2021

Citation: Moreno García MA, Muñoz Moreno CY, Chávez Guajardo EG, Maldonado Tapia HM, Vargas Rodríguez MR, et al., Contributions from the Autonomous University of Zacatecas in the Epidemiology, Diagnosis and Treatment of Trichinellosis, 1986-2021. Biomed J Sci \& Tech Res 39(4)-2021. BJSTR. MS.ID.006322.

Keywords: Epidemiology; Diagnosis; Treatment; Trichinellosis; Autonomous University of Zacatecas

\begin{abstract}
Trichinellosis is worldwide distributed zoonosis, which affects humans and other living organisms including mammals, birds, and reptiles. The distribution is facilitated by the modifications of ecosystems, and the repercussions on nature, such as increase of greenhouse gases and the increase of temperature. Having economic, social, and health repercussions. The present work aims to present the research carried out at the Autonomous University of Zacatecas from the year 1986 to 2021, on Trichinellosis parasitosis caused by parasite Trichinella spiralis, working on the biology of the parasite, the life cycle, experimental models, diagnosis, and treatments with drugs and immunogens.
\end{abstract}

Methodology: Reproduction of the life cycle of Trichinella spiralis, in various experimental models: murine, dog, cat, rabbit, pig. Standardization of direct plate compression techniques, artificial digestion and hematoxylin-eosin and indirect double micro-immunodiffusion, DOT-ELISA, Immunofluorescence, Wester-blot, and intradermal reaction. Evaluation of drugs albendazole, quinfamide, products such as Lactobacilli, and immunomodulators such as VITS, immunogens the total extract of Trichinella spiralis, the $45 \mathrm{KDa}$ band, and different immunization schemes and routes. Detection of the parasite in domestic rat, dog, pig and human. Elaboration of a diagnostic KIT.

Results: In this project Long Evans rats and Balb-C mice were used as experimental murine models to maintain the parasite strain viable and maintain its pathogenicity characteristics (1986-2021). In all the reproduced models the direct and indirect techniques are useful and Wester-Blot shows a characteristic 42-45-48-KDa triplet. In experimental murine and pig models, the use of albendazole is effective against Trichinellosis with treatments of 14 days, destroying the nurse cell, likewise the use of Lactobacilli and VITS is effective and reduces the parasite load.On the other hand, treatments with immunogens, in the experimental models, the total soluble antigen, the $45 \mathrm{kDa}$ band, was statistically significant in the different schemes and routes of administration. It was detected in domestic rats, pigs, dogs, and humans. Finally, a proposal of a diagnostic kit for the field, with the DOT-ELISA technique is in development.

Conclusion: During the last decades it has been settled a well-established experimental murine model, for the study of the biology of Trichinella spiralis. Our research has shown that the correct use of albendazole as a treatment is effective. 
Another major finding is that the total extract of T. spiralis and the band of $45 \mathrm{KDa}$ are excellent immunogens, and confirmatory technique of Trichinellosis by Wester-Blot, and the rest of the techniques are useful in epidemiological diagnoses and for research. The present study contributes to the understanding of Trichinellosis, as a silent disease present in the state of Zacatecas, Mexico, which unfortunately is not correctly diagnosed as in the other places of the Mexican Republic. Hence the importance of prevention. The mainly carriers are rats, pigs, and recently wild boar. Some of these animals are already consumed regularly in our region posing a risk for the spreading of the disease.

\section{Introduction}

In Mexico, the first reports of Trichinellosis were by Dr. Olvera in 1896 [1], later by Dr. Perrin in 1939, and Dr. Mazzotti carried out the first epidemiological studies in 1943 [2]. The latest reports from the national health secretary are those obtained from 19901994, 2000-2002, 2014, 2015 and 2016, with a total of 1122 cases, the states with the highest number of cases from 1990-2016 were: Hidalgo 216, Chihuahua 113, Veracruz 81, Jalisco 76 and Oaxaca 55, Zacatecas no cases have been reported since 1994, and from 1990199440 cases were reported [3].

Zacatecas is a state of the Mexican Republic located in the north of the country, it has an area of $75,275.3 \mathrm{Km}^{2}$, a population density of 21.5 inhabitants $/ \mathrm{Km}^{2}$ that represents 3.8 of the national territory and with a population of 1,622,138 inhabitants. distributed in 58 municipalities being the most populated Guadalupe, Zacatecas and Fresnillo, which represents $1.3 \%$ of the national population. There are 95 men for every 100 women. 59.4\% have basic education, $77.5 \%$ have piped water, $96.3 \%$ have drainage, $99.3 \%$ electricity, $79.7 \%$ have some medical safety regime. The economically active population is dedicated to agriculture, livestock, mining, services and industry [4]. The Autonomous University of Zacatecas (UAZ) is considered the civilizer of the north, it was founded in 1832, and its autonomy was in 1968, which currently has an approximate population of 40 thousand students and 6 thousand teachers and administrative personnel UAZ 2020.

Trichinellosis was detected for the first time in Zacatecas in 1975, and 4 outbreaks were reported in 1978, the most significant being that of Laguna de Carretero (Municipality of Villanueva), with a fatality of 33\%, from 1979-1988 17 outbreaks were reported. The most important being Valparaíso (with one death), and Pozo de Gamboa where a 20-year-old pregnant woman lost the product. Trichinellosis was found to be more frequent in urban than rural areas, the age group from 15-44 years being more affected (49\% of cases) and referring to sex 1: 1.8 male / female. Zacatecas currently has 58 municipalities and Zacatecas, Villanueva, Valparaíso, Panucho, Jerez, Jalpa and Guadalupe were affected at that time, and the transmission route was due to the consumption of poorly sewn chorizo, the diagnosis was by direct plate compression techniques, that received the name of trichinoscopy, and by the indirect technique of micro immuno-diffusion-double [5]. The objective of the present work is to make a report of the work carried out in this parasitosis during the period of 1986-2021 in the Autonomous University of Zacatecas.

\section{Materials and Methods}

a) Implementation of experimental models, murine (Balc / C mouse, Long Evans rat), domestic dog, rabbit, York pig [6-13].

b) Characterization of the life cycle of Trichinella spiralis $[11,14,15]$.

c) Establishment of direct techniques (plate compression, artificial digestion, and hematoxylin / eosin) and indirect (double microimmunodiffusion, Dot-ELISA, IFI, Western Blot, intradermal reaction) for the diagnosis of Trichinella spiralis [16-23].

d) Evaluation of albendazole in a murine and pig experimental model, its evaluation with $3,5,7,10,14$ days of treatment. In the initial phase of the infection, in the intestinal and muscular phase $[11,23,25,26]$.

e) Evaluation of albendazole in pregnant rats, with the same treatment days [27].

f) Evaluation of the total antigen of Trichinella spiralis in murine and pig models, and of the $45 \mathrm{KDa}$ band in murine models. In the intestinal, muscular phase and after 30,60, 90 and 120 days of immunogen application. The purpose was to evaluate the modifications of the T. spiralis nurse cell in Long Evans rats immunized with total soluble antigen of $T$. spiralis and sacrificed at different times. We worked with 25 male rats of 2 and a half months of age, immunizing 20. Subsequently, the 25 rats were challenged with infected T. spiralis meat, sacrificing 5 rats every month, plus a control rat per 4 months, when sacrificing them, direct plate compression techniques, artificial digestion and the hematoxylin-eosin technique were performed; indirect MIDD and Western Blot techniques were performed on the sera [11,26,28-32]. 
g) To evaluate the protective effect of Trichinella spiralis Total Soluble Antigen combined with bacterial vaccine and VITS via sublingual route in Long Evans rats and to evaluate Lactobacillus casei and VITS in intestinal infection by T. spiralis in a murine model [11].

h) In all treatment models, groups of 5 animals were used, the healthy control, Trichinella spiralis infection control, and the different groups according to the treatment, and direct and indirect techniques were performed. And the results were analyzed by statistical analysis of ANOVA or Student's t test.

i) Epidemiological studies in humans, pigs, dogs, and domestic rats for the detection of Trichinella spiralis, by indirect techniques of double microimmunodiffusion, Dot-ELISA and Western Blot [33-35].

j) Evaluation of a Diagnostic Kit by Dot-ELISA for detection in the field.

\section{Methodology}

Used in the experiments were obtained from the animal facility of the Academic Unit of Biological Sciences of the Autonomous University of Zacatecas.

The parasite (Mexican strain) was identified with Edoardo Pozio $\mathrm{PhD}$, in the Istituto Superiore di Sanita in Rome, Italy 2000, and has been maintained by serial passage in mice and rats since 1986 at the Laboratory of Cell Biology and Microbiology at the Academic Unit of Biological Sciences from the Autonomous University of Zacatecas, Mexico. All the animals were maintained in controlledtemperature rooms and fed with rodent balanced food $[6,13]$.

\section{Ethical Approval}

This study was reviewed and approved by the Bioethics Committee of the Biology Faculty of the Autonomous University of Zacatecas, in accordance with the Official Mexican Norm (NOM-062Z00-1999), published by the Secretariat of Agriculture, Livestock, Rural Development, Fisheries and Food (SAGARPA) in the Official Gazette of the Federation (Mexico) on June 28, 2001 [13].

\section{Direct Techniques}

\section{Plate Compression Technique}

For the plate compression technique, approximately $5 \mathrm{mg}$ of tissue were used (diaphragm, masseter, tongue, intercostals, leg), each sample was placed between 2 lamellae and compressed, occupying an area of $1 \times 5 \mathrm{~mm}$, it was observed to the optical microscope, with the $10 \mathrm{x}$ and $40 \mathrm{x}$ lens $[10,11,33,36,37]$.

\section{Artificial Digestion Technique}

$30 \mathrm{~g}$ samples were used of homogenized tissue, and they were incubated at $37{ }^{\circ} \mathrm{C}$, in a sack-shaped tulle sieve, suspended in a
$0.3 \%$ solution of pepsin $(10,000 \mathrm{U})$ and $37 \% \mathrm{HCl}(0.2 \mathrm{M})$ in 500 $\mathrm{ml}$ of distilled water, inside a separating funnel; 24 hours later, the larval package was separated with the ILs, which were deposited at the bottom of the funnel, observed in a newbawer camera under an optical microscope with a $10 \mathrm{X}$ lens, and the larval package was quantified $[7,25,36,38]$.

\section{Hematoxylin-Eosin Staining}

Hematoxylin-Eosin (H-E) stain. Leg, tongue, and diaphragm samples were taken from each experimental model. The tissues were fixed in 10\% buffered formalin for 24-48 hours. Subsequently, they were transferred to $70 \%$ ethyl alcohol for automatic processing for approximately 12 hours in two steps of $70 \% \mathrm{OH}, 80 \% \mathrm{OH}, 96 \% \mathrm{OH}$, $100 \% \mathrm{OH}$ and xylol. From this last step, the samples were removed and embedded in paraffin, forming support blocks for making 5-8 $\mu \mathrm{m}$ thick histological sections on a Leica Model 820 microtome. The sections were placed in a float bath at $50^{\circ} \mathrm{C}$ and they were lifted on a slide to dry, deparaffinize for an hour in an oven and then go on to the staining process with the Hematoxylin and Eosin technique according to the criteria of Viloria [28].

\section{Indirect Techniques}

\section{Double Microimmunodiffusion Technique (MIDD)}

For double immunodiffusion, a $1 \%$ agar gel was made in distilled water with sodium azide, to avoid contamination; It was placed in an amount of $4.5 \mathrm{~mL}$ at $55{ }^{\circ} \mathrm{C}$ on a glass slide, once in solid form, the rosette was formed with a hole-hole, ensuring an equidistance of $0.5 \mathrm{~cm}$ between well and well; the comparison was carried out by always placing the antigen in an amount of $10 \mu \mathrm{L}$ $(10 \mu \mathrm{g})$ in the center and, around it, a serum of known reactivity, (in the same proportion by undiluted volume), leaving at room temperature environment in a humid chamber for 24 to 48 hours, until precipitation lines are observed between the positive serum and the antigen; then the gel was stained with Coomassie brilliant blue G $250,25 \%$ by volume [10].

\section{Dot-ELISA}

Several nitrocellulose papers were squared, depending on the number of samples to be used, each $1 \mathrm{~cm}^{2}$ square a $10 \times 5 \mathrm{~cm}$ paper. The antigen was placed on the undiluted paper placing the equivalent of $10 \mu \mathrm{g} / \mu \mathrm{L}$, then it was allowed to dry at room temperature and once dry, it was proceeded to block with $3 \%$ fat-free milk in PBS this for 18 hours. Once the blocking time had concluded, it was washed once with PBS 0.5\% Tween 20 for 10 minutes and 2 consecutive times with PBS for 10 minutes each time, then, $10 \mu \mathrm{L}$ of each test serum was placed in each square and incubated again with 3\% fat-free milk in PBS for an hour and a half, at the end of this time we proceeded to wash again with PBS $0.5 \%$ Tween 20 for 10 minutes and 2 consecutive times with PBS for 10 
minutes, then the second antibody, Anti-IgG, Anti-IgM or Anti-IgA at a concentration of 1: 2000 in PBS conjugated with peroxidase, 10 $\mu \mathrm{L}$ of the second antibody and allowed to dry at room temperature, once dry it was incubated once more with Milk 3\% fat free in PBS for an hour and a half and the container containing the paper was completely covered with aluminum foil. At the end of the hour and a half, the paper was washed with PBS Tween 20 at $0.5 \%$ for 10 minutes and 2 consecutive times with PBS for 10 minutes. The paper was then developed with 3,3-diaminobenzidine DAB, using $37 \%$ hydrogen peroxide as substrate $[11,19,27]$.

\section{Indirect Immunofluoresence (IFI)}

The infective larvae (IL) were obtained from the rat muscle infected with T. spiralis, $20 \mu \mathrm{L}$ of IL were taken and washed for three periods with PBS for $5 \mathrm{~min}$ in magnetic stirring, they were incubated with $20 \mu \mathrm{L}$ of the first Ab with a 1: 100 dilution for 45 min with PBS, they were washed with PBS on 3 occasions for 5 min in magnetic stirring, the liquid was extracted with care to avoid absorbing the LI, $200 \mu \mathrm{L}$ of the monovalent anti-gamma-fluorescein conjugate was added (IgG dilution 1: 1000), it was incubated for 45 min at $37^{\circ} \mathrm{C}$, the liquid phase was extracted, 3 washes were carried out with PBS in magnetic stirring for 5 min each, lamellae were mounted with the IL, covering them with cover objects and sealed with resin, they were observed under a confocal microscope [38].

\section{Western Blot (WB)}

The product obtained from the polyacrylamide gel run was transferred to NC paper [17], using the Transblot-Cell camera (BioRad) at 35 volts, overnight at $4{ }^{\circ} \mathrm{C}$. The NC paper was dyed with fast green for $5 \mathrm{~min}$. With constant stirring, the dye was removed and decolorized in distilled water, to verify protein transfer, it was allowed to dry and the strips of the approximate width of each lane $(0.5 \mathrm{~cm})$ were cut. After the above, each strip was covered with a solution of PBS-3\% milk powder and $0.15 \%$ sodium azide at $4{ }^{\circ} \mathrm{C}$, with constant stirring overnight. They were then washed 3 times for 10 min. with PBS, incubation was continued for $1.5 \mathrm{~h}$. with the sera of the rats in a dilution of 1: 100 in PBS-3\% milk powder at 37 ${ }^{\circ} \mathrm{C}$ with constant agitation, subsequently they were washed twice with PBS- $0.3 \%$ Tween 20 for 10 min and three more with PBS for another 10 minutes. Then, they were incubated with the second anti-rat IgG antibody, conjugated with peroxidase 1: 2000 PBS-3\% milk powder for $1 \mathrm{~h}$., At room temperature, with shaking, then they were washed 2 times with PBS-Tween 20 at 3\% and rinsed with PBS, for $10 \mathrm{~min}$. The Banding pattern of each strip was developed with 3,3' di amino-benzidine (DAB), $50 \mathrm{mg}$ in $100 \mathrm{~mL}$ of PBS, using, as a substrate, $37 \%$ hydrogen peroxide [39].

\section{Intradermal Reaction (IDR)}

Intradermal reaction was applied with Total Soluble Antigen of T. spiralis which were 10 units (10 $\mu$ g of protein), the area of application of the AST was observed at 2, 24 and 48 hours $[17,11]$.

\section{Obtaining Immunogens}

The antigen of T. spiralis was obtained, by means of extraction with liquid nitrogen, the infecting larvae were obtained by the artificial digestion technique, liquid nitrogen was added in sufficient quantity to cover the IL and by bursting the exit of antigenic components were centrifuged at $3500 \mathrm{rpm}$ for $1.5 \mathrm{hrs}$. The supernatant was the soluble antigen of T. spiralis, whose protein concentration was determined and used in the different immunological tests, and as an immunogen (secretion / excretion antigens) in protection studies $[6,7,18,19,11,36]$.To determine that the antigen had the adequate protein concentration, a standard curve was obtained using bovine serum albumin, according to the methodology of Bradford, 1976, adjusting the concentration of proteins obtained to an optical density of $610 \mathrm{~nm}$ using Coomassie blue at $0.06 \%$ prepared in $2.2 \% \mathrm{HCl}$. The value of the optical density of the antigen was interpolated, to that of the standard curve of albumin, the concentration of proteins contained in the two types of antigenic extract was obtained [18].To obtain the immunogenic protein of $45 \mathrm{kDa}$, the AST was subjected to polyacrylamide gel electrophoresis to separate by molecular weight (MW) the proteins that were identified by a PM marker of the $45 \mathrm{kDa}$ protein and by elution of bands the required protein was obtained.

\section{Results}

The experimental models of infection were implemented in a murine model, Balb / C mouse, Long Evans rat, domestic dog, rabbit, York pig (Figure 1), in all there was the reproduction of the infection and the life cycle, handling an IL per gram of weight. It was in pigs that we observed the clinical picture of the disease: diarrhea in the intestinal phase, and in the systemic and muscular phase: eyelid edema, joint injury, increased temperature. At sacrifice, IL was detected in muscle and brain tissue (Figures 2 and 3). 

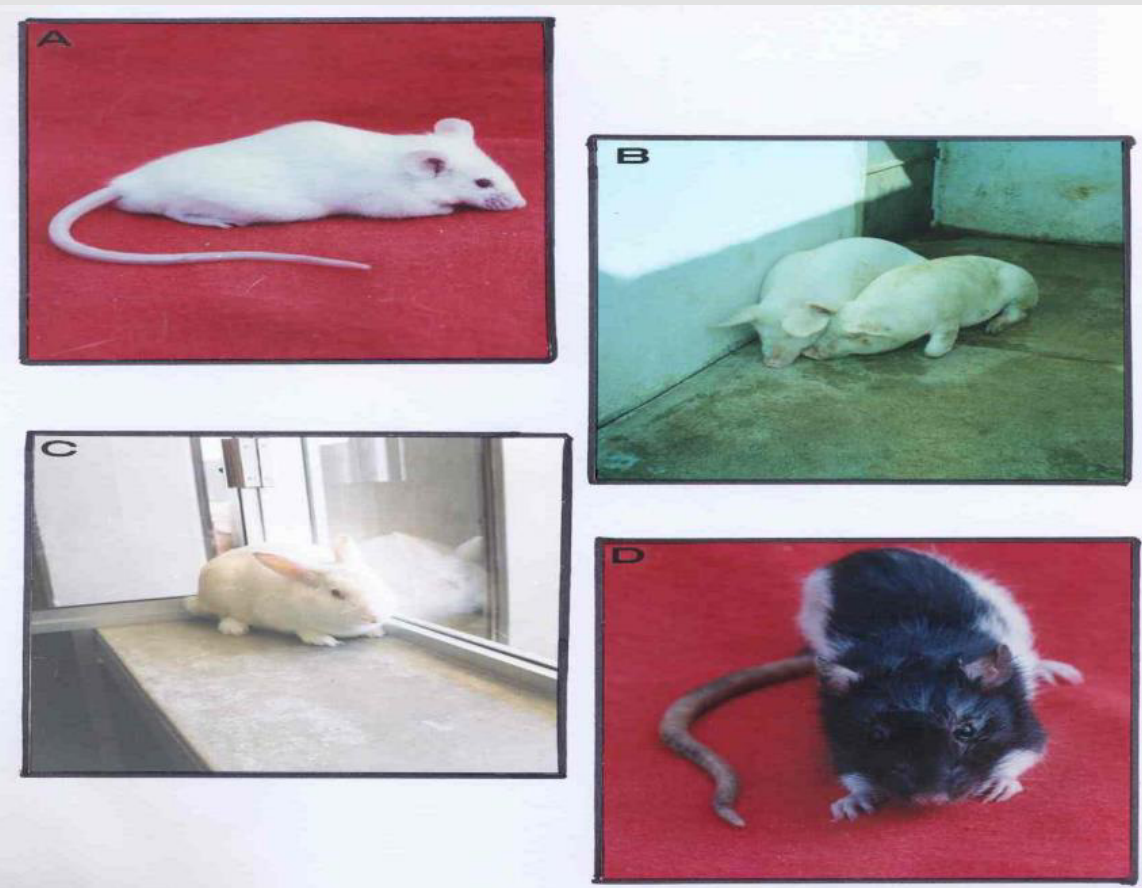

Figure 1: Experimental models used: Balc / C Mouse, York Pig, New Zealand Rabbit and Long Evans Rat. Material obtained in the Laboratory of Cell Biology and Microbiology UAZ.

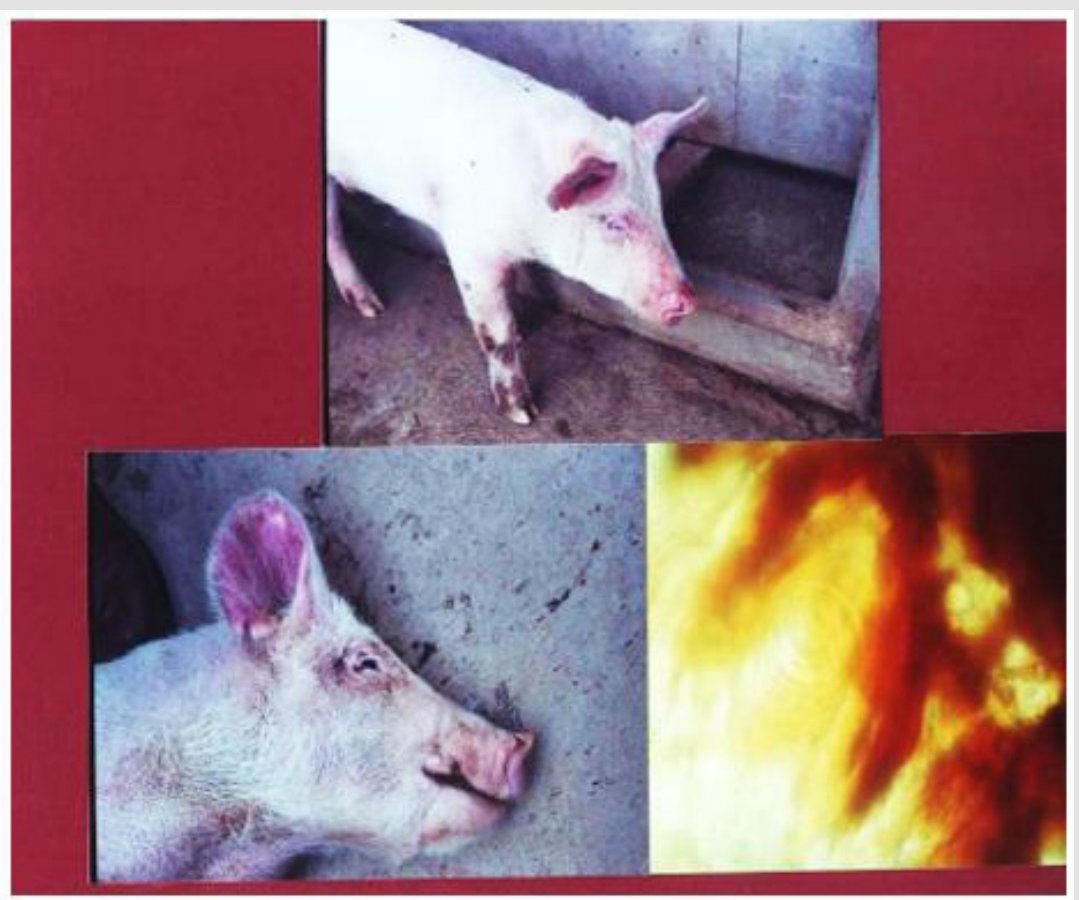

Figure 2: The York pig is shown, which presents joint lesions, eyelid edema, skin erythema, and presents an increase in temperature. Upon sacrifice in the brain, IL was observed under a 40X light microscope and hemorrhage around it, by the plate compression technique. Material obtained in the Laboratory of Cell Biology and Microbiology UAZ. 


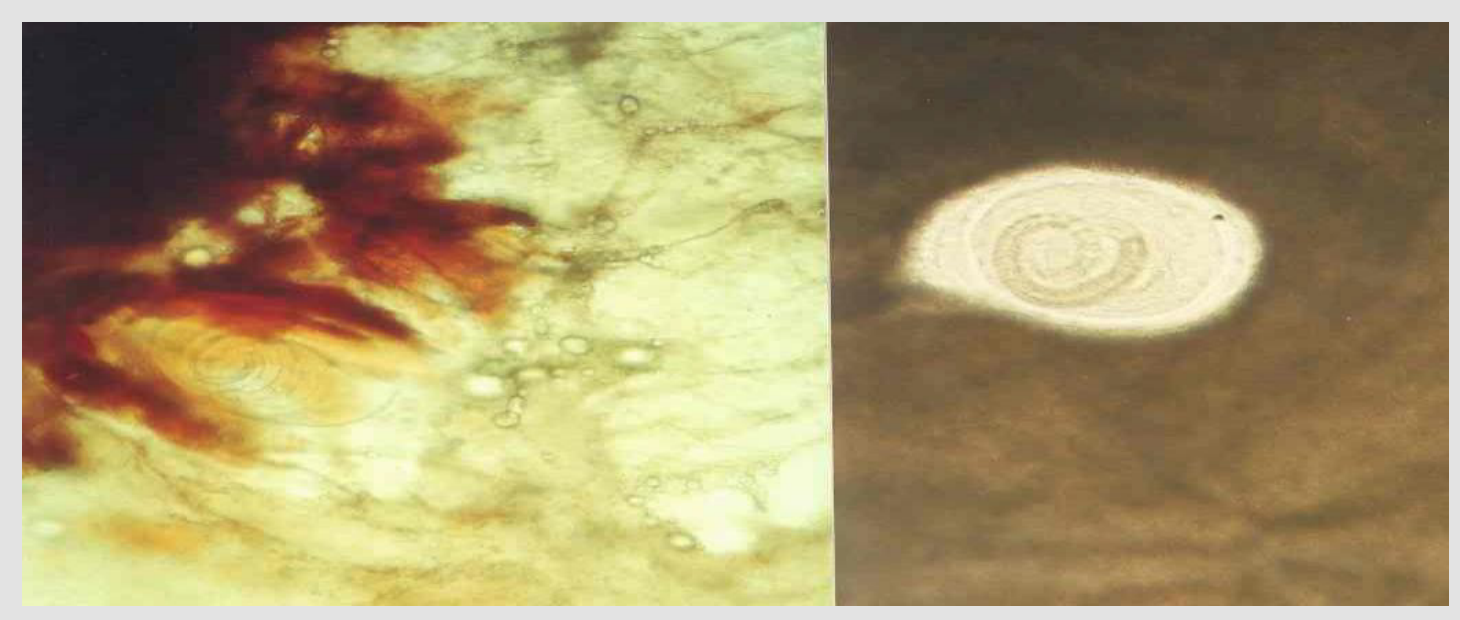

Figure 3: Compression image of the brain plate shows an IL with hemorrhage under a 40X optical microscope, and another in its cyst, but not as we usually see it in muscle. Material obtained in the Laboratory of Cell Biology and Microbiology UAZ.

\section{Characterization of the Life Cycle of Trichinella Spiralis}

The 3 stages of Infective Larvae (IL) were observed in muscle, male and female adults in intestine and Newborn Larvae (NL) in intestine and muscle.
Male and female adults (Figure 4), technical observation of plaque compression and the small intestine was performed with the Fernandez Balls Technique (Figures 5\&6).

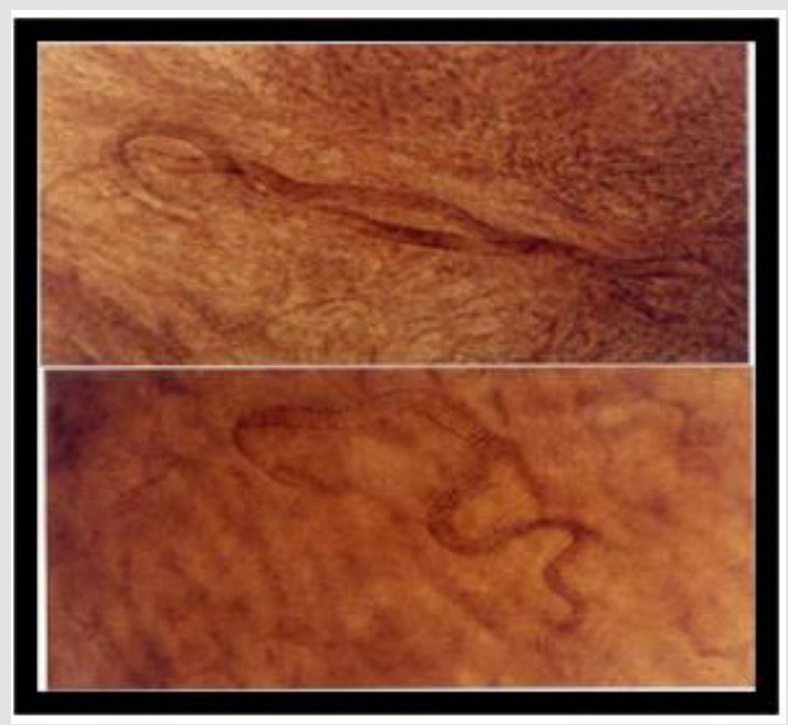

Figure 4: Life Cycle, the male and female adults are observed in the upper part, and in the lower part the female, which is in the pregnant stage, under an optical microscope of light at 10X. Material obtained in the Laboratory of Cell Biology and Microbiology UAZ. 


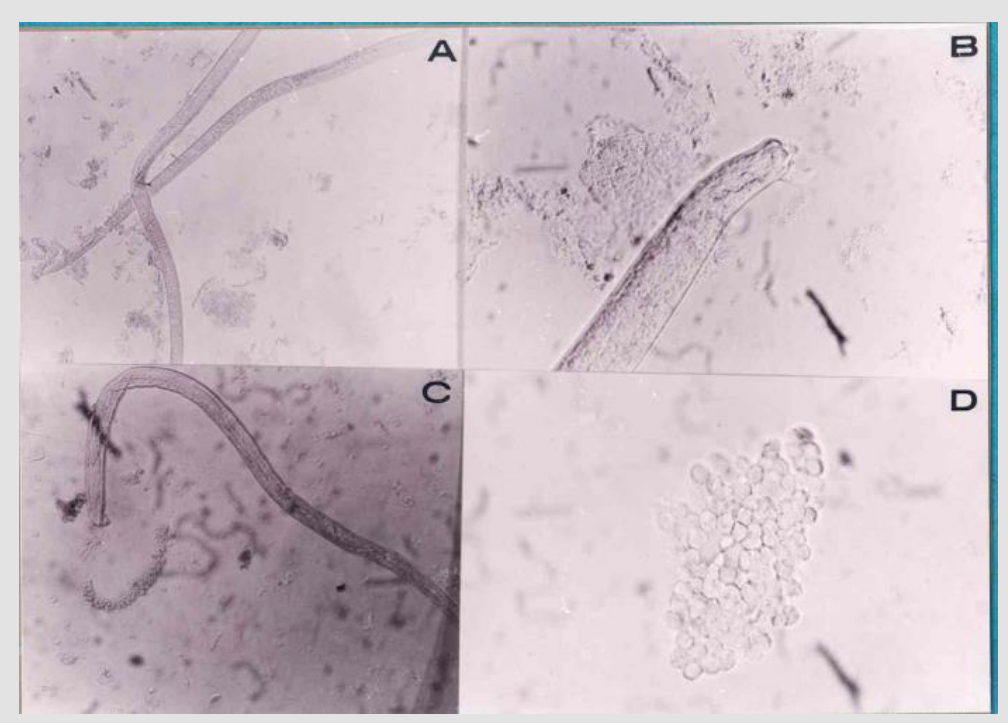

Figure 5: Obtaining adults by Bolas Fernandez technique, in A) Appearance of male and female adults, B) Male and its copulatory organ is observed, C) Expulsion of spermatozoa, D) Non-cialiated spermatozoa of Trichinella spiralis male. Observed under a $40 \mathrm{X}$ light optical microscope. Material obtained in the Laboratory of Cell Biology and Microbiology UAZ.

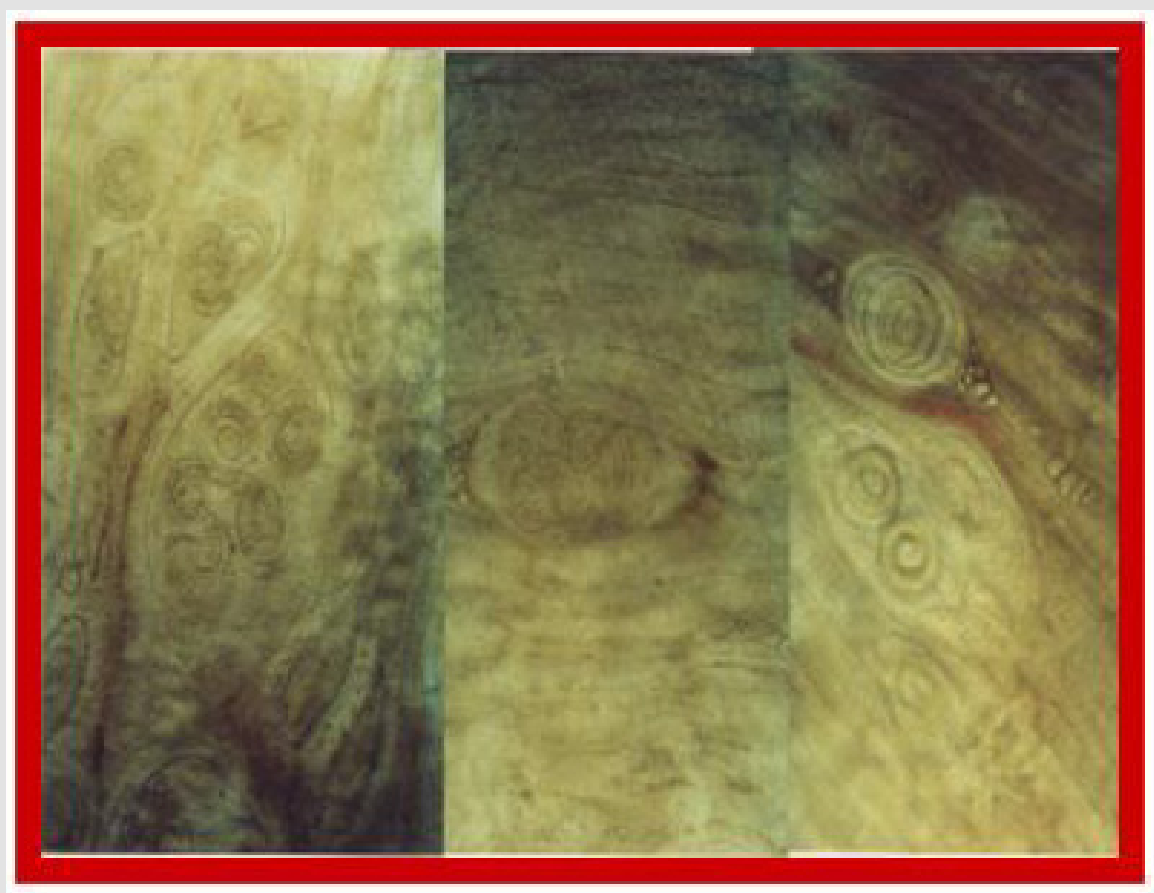

Figure 6: Plate compression technique observed under a 10X light optical microscope, IL of T. spiralis in its cyst or nurse cell, in the images there are from 1 IL to 6 in a single cyst, in the model where we observed a higher number was in the one with the York pig. Material obtained in the Laboratory of Cell Biology and Microbiology UAZ. Muscle tissue, Infective larvae finding from 1 to 6 in a single cyst (Figure 6).

\section{Direct Diagnose Techniques}

In all the experimental models by plaque compression (Figure 7), artificial digestion (Figure 8) and the Hematoxylin-Eosin technique, IL from Trichinella spiralis (Figure 9) were observed.
Indirect Techniques: Indirect techniques, double microimmunodiffusion (MIDD, Figure 9.), Dot-ELISA, Immunofluorescence (IFI, Figure 10), Wester Blot (WB, Figure 11) and Intradermoreaction were positive, in WB a triplet of 42,45 and $48 \mathrm{kDa}$. The intradermal reaction is effective from the first month of 
infection with T spiralis, which is a very timely diagnosis for the pig without the need for a specialized infrastructure, as well as being inexpensive and can easily be carried out to the field with simple animal handling and not very aggressive, with a presumptive diagnosis after 2 hours of application of the intradermal reaction and confirmatory after 24 and 48 hours, which can prevent infection in man and even other animals in a timely manner.

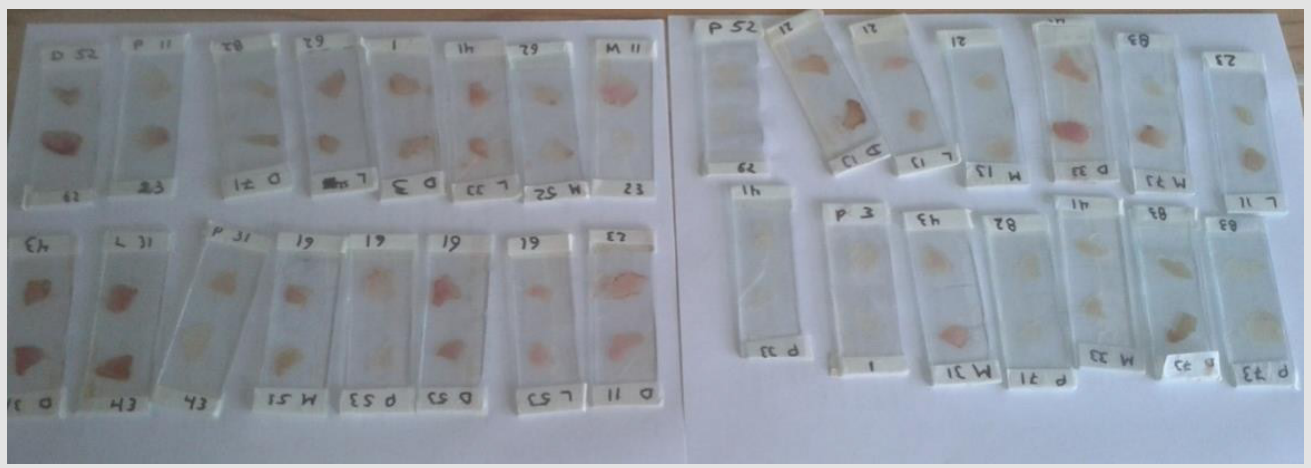

Figure 7: Plate compression technique. Material obtained in the Laboratory of Cell Biology and Microbiology UAZ.
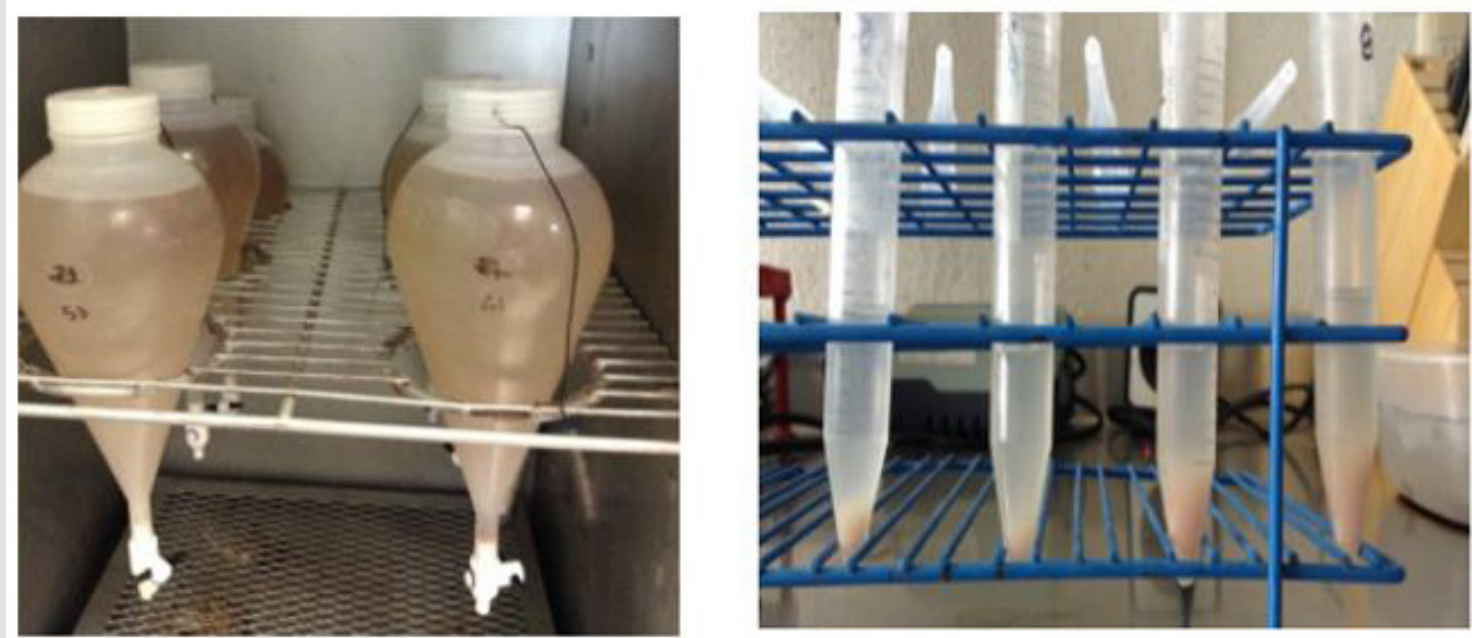

Figure 8: Shown in A) Separation funnels, with meat in digester solution in an incubator at 37 degrees centigrade. B) Conical tubes with a Trichinella spiralis IL bundle at the bottom. Material obtained in the Laboratory of Cell Biology and Microbiology UAZ.

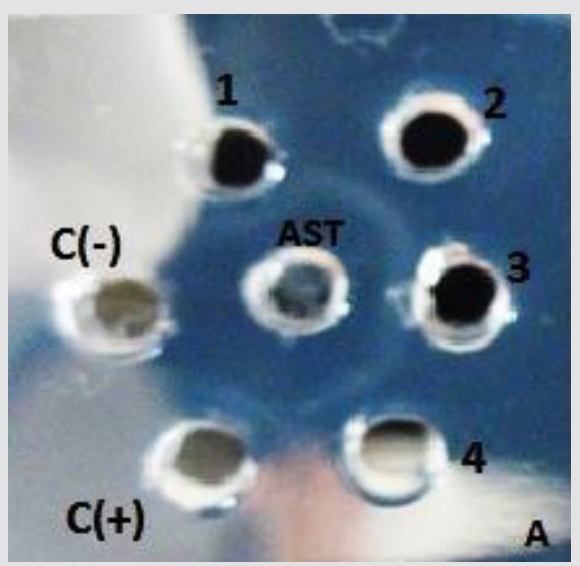

Figure 9: MIDD 1,2,3,4 positive sera from the murine model are shown, the positive and negative control, it is a specific technique with low sensitivity, but useful in research and massive sampling. Material obtained in the Laboratory of Cell Biology and Microbiology UAZ. 


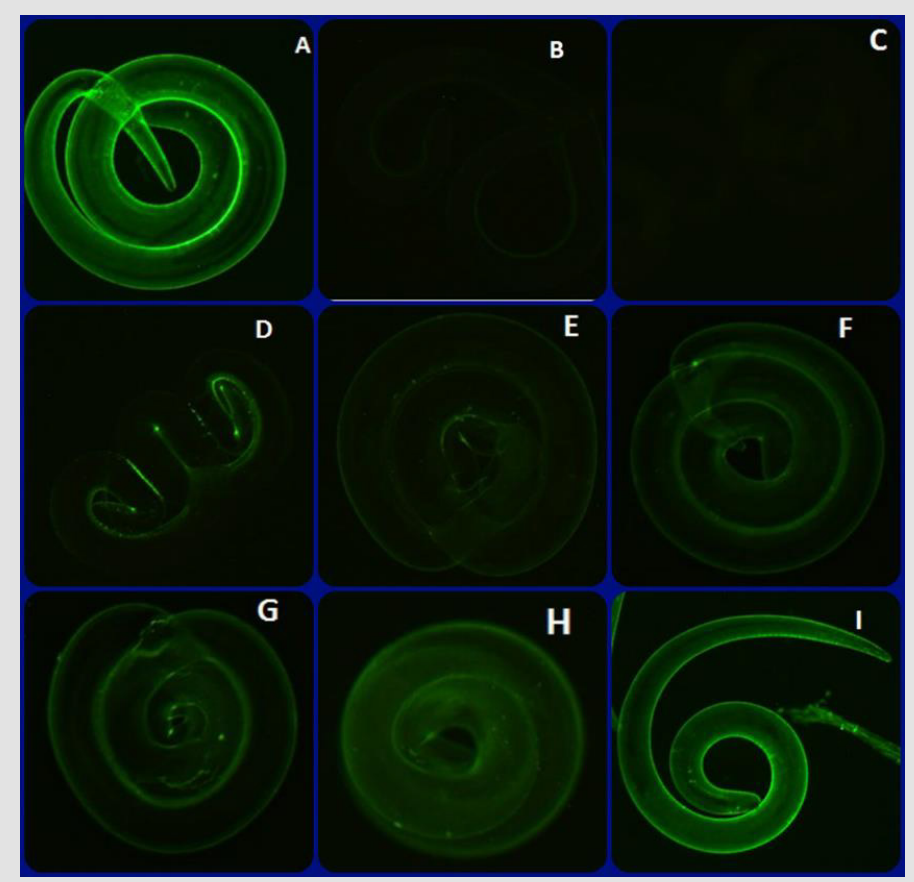

Figure 10: The IFI technique is shown, observed under a 100X confocal microscope, A) Trichinella spiralis positive serum B) and C) negative sera, D), E), F) positive sera from a murine model, G) positive serum from a domestic dog model, H) and I) positive sera of the York pig model, with IgG type immunoglobulin. Material obtained in the Laboratory of Cell Biology and Microbiology UAZ.

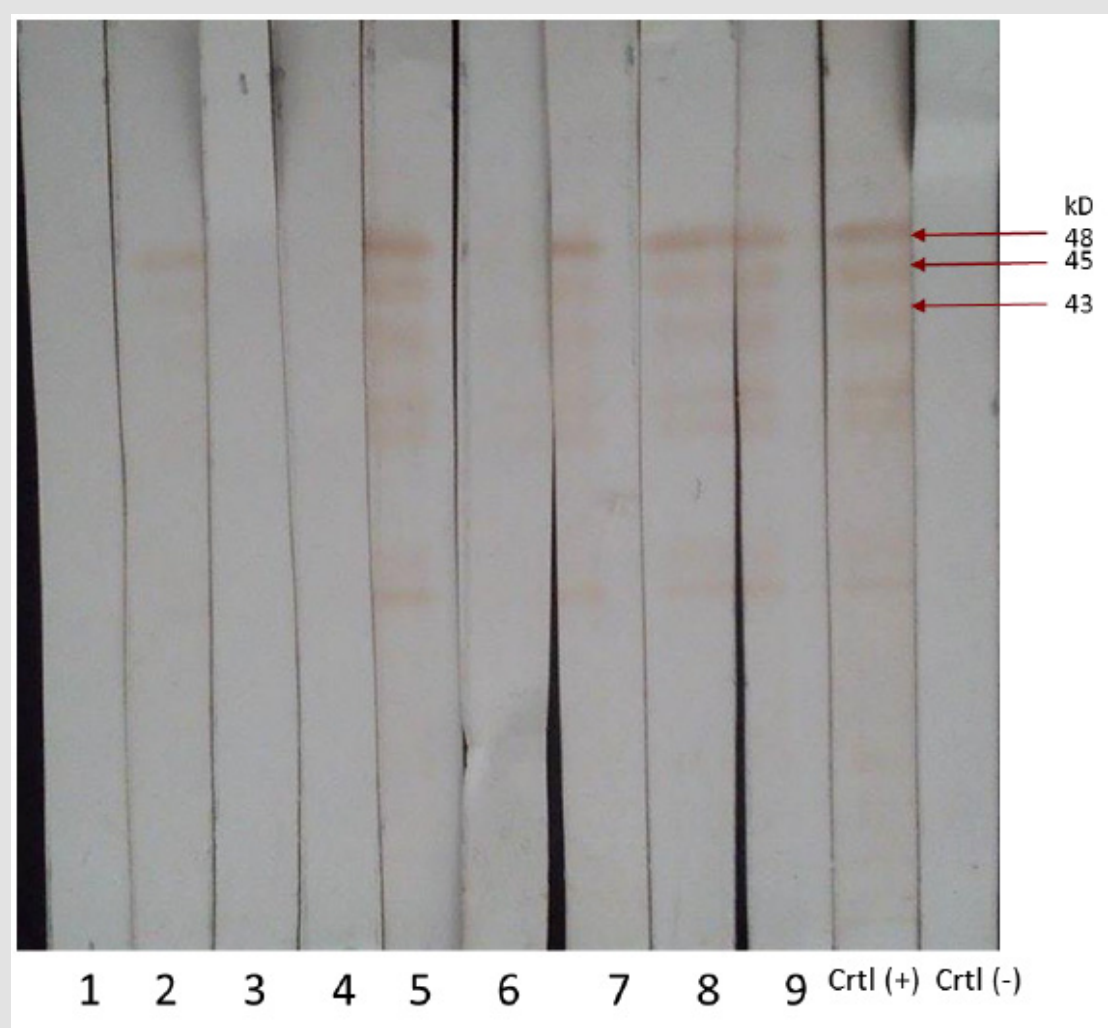

Figure 11: It shows 1,3,4 negative murine model sera, 2, 5 and 6 positive murine model sera, 7, 8 positive sera from York pig model, 9 positive serum from dog, and positive control serum for Trichinella spiralis and negative control serum of the murine experimental model. In the positive ones, the triplet of 42,45 and $48 \mathrm{kDa}$ is observed. Material obtained in the Laboratory of Cell Biology and Microbiology UAZ. 
Evaluation of treatment with albendazole, it was effective from day 7,10 and 14, both in intestinal and muscular phase (Figure 12), murine and pig models, being statistically significant compared to the infected control without treatment with a $-\mathrm{P}<0.001$, by ANOVA, when evaluating the parasite load by artificial digestion.When performing the trypan blue technique to see viability of the IL obtained from the digestion, they were dead, there was penetration of the dye.

Albendazole evaluation in pregnant rats, phenotypic modifications were observed from day 3 of treatment, being more important with 14 days of treatment (Figure 13).
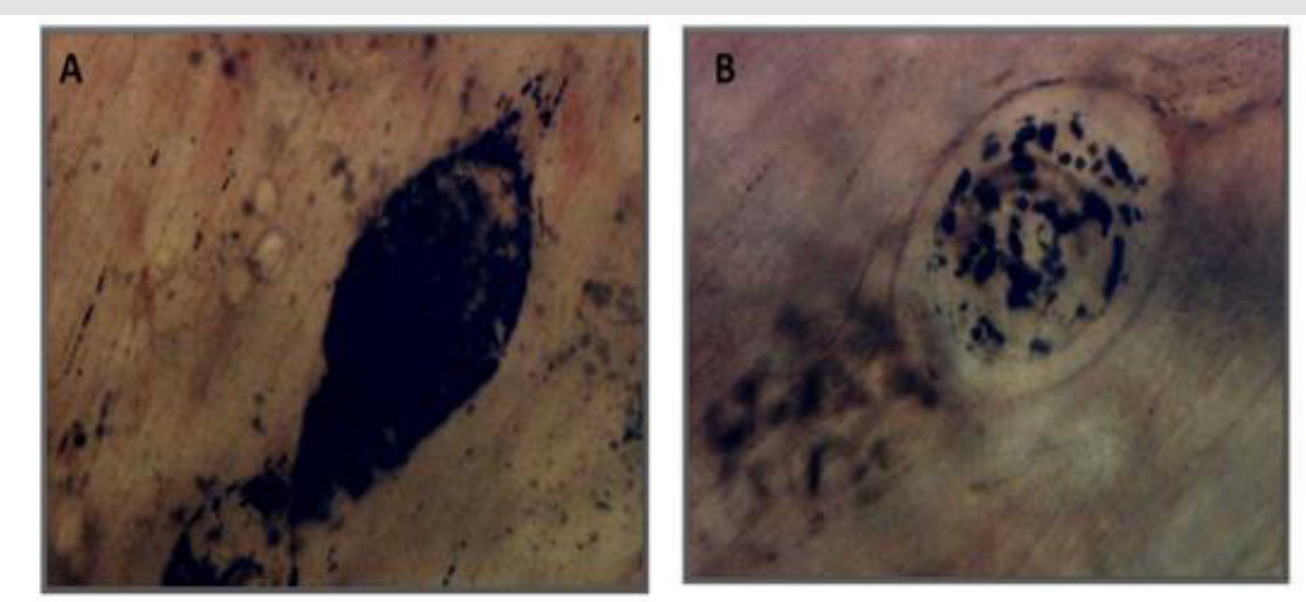

Figure 12: A plate compression technique is shown under a 10X light optical microscope, A) shows with 14 days of albendazole treatment, B) shows with 10 days of albendazole treatment in a murine model. Material obtained in the Laboratory of Cell Biology and Microbiology UAZ.

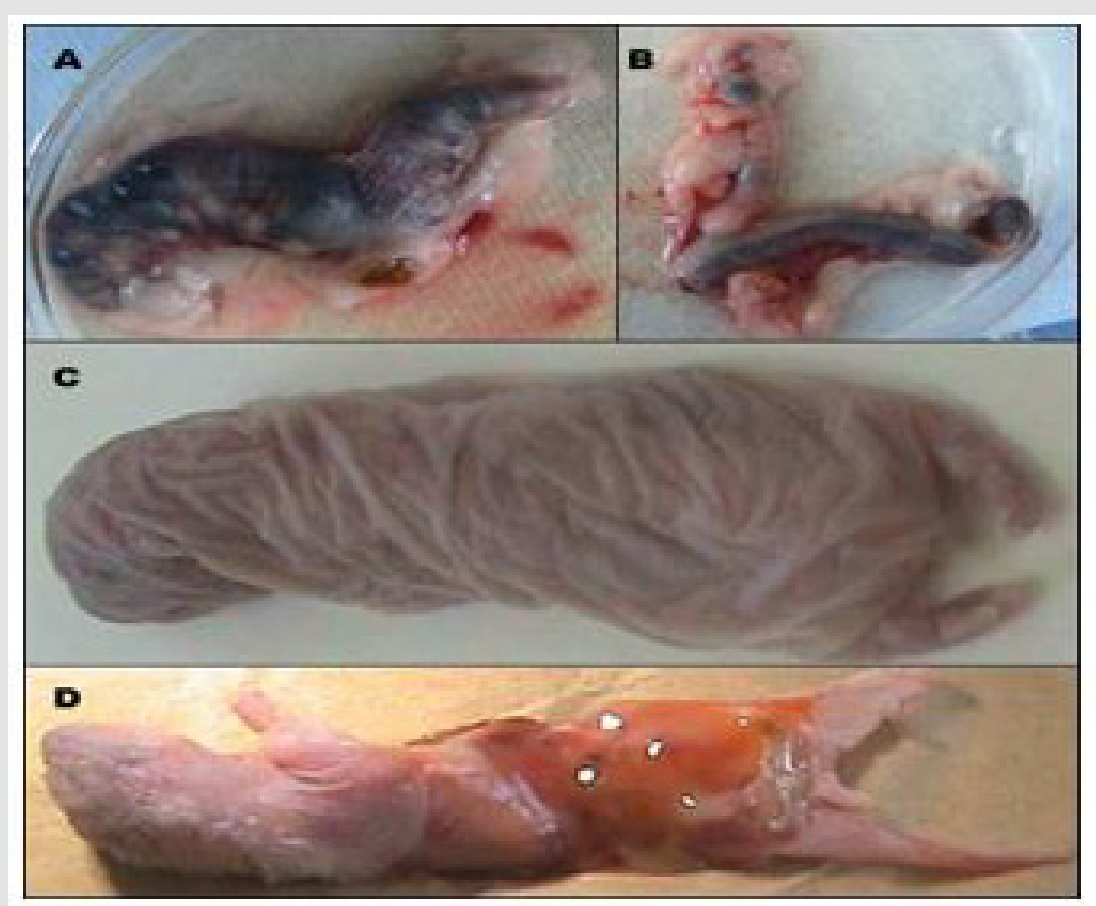

Figure 13: A) and B) Uterine horns obtained from rats with 15 days of Tx. C) Image of a dead rat with alterations in the spine and extremely dehydrated and lax skin. D) ventral image of the rat showing the absence of vital organs in both the thoracic and abdominal cavity. Material obtained in the Laboratory of Cell Biology and Microbiology UAZ. 


\section{Evaluation of the Total Soluble Antigen of Trichinella spiralis in Murine and Pig Models}

A statistically significant protection effect was observed in muscle phase, by analysis of variance $p<0.0001$. (Figure 14), in relation to the infection control group.When evaluating the $T$. spiralis implant at 30, 60, 90 and 120 days it is observed how the recovery of the tissue occurs, The modifications in the nurse cell of T. spiralis in tissues of Long Evans rats immunized with AST and sacrificed in Different times were evident with the direct techniques of C / P, D / A and H / E staining (Figure 15), it is observed how the encystment is lost and the spiral is no longer viable, being statistically significant with a value of $\mathrm{P}<$ than 0.01 . By ANOVA.

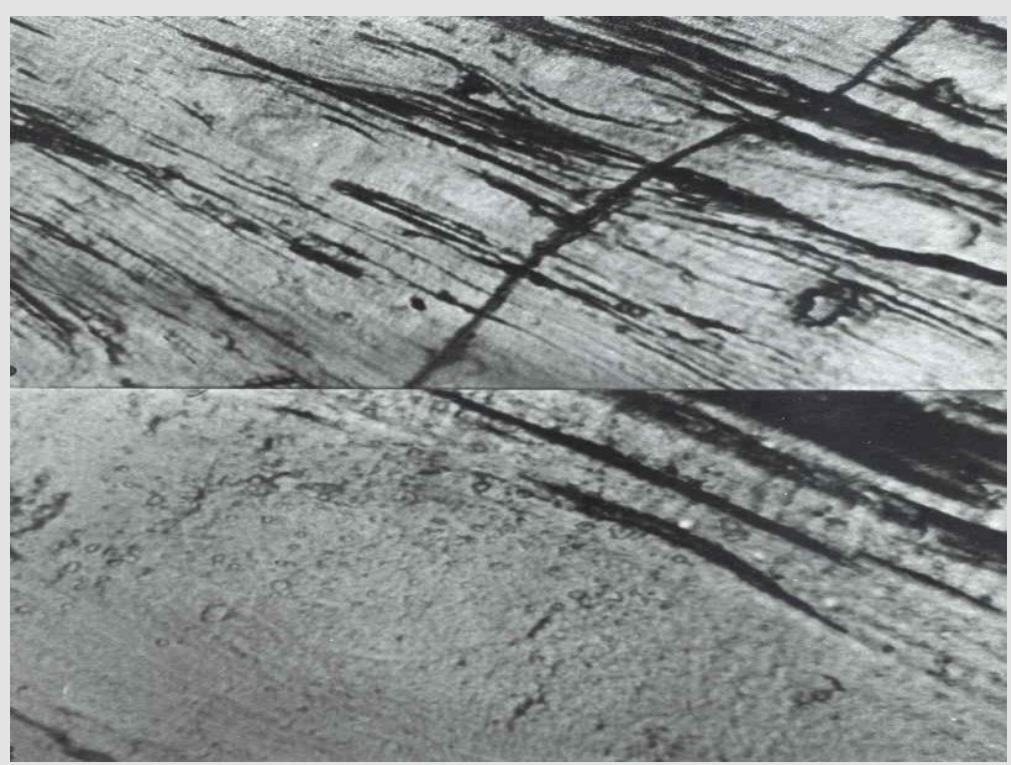

Figure 14: Compression tissue is shown on a plate, where the IL of Trichinella spiralis is not found, in the super part observed with the 40X optical microscope the empty cyst and in the lower part at 100X the absence of the IL of Trichinella spiralis is confirmed spiralis. Material obtained in the Laboratory of Cell Biology and Microbiology UAZ.

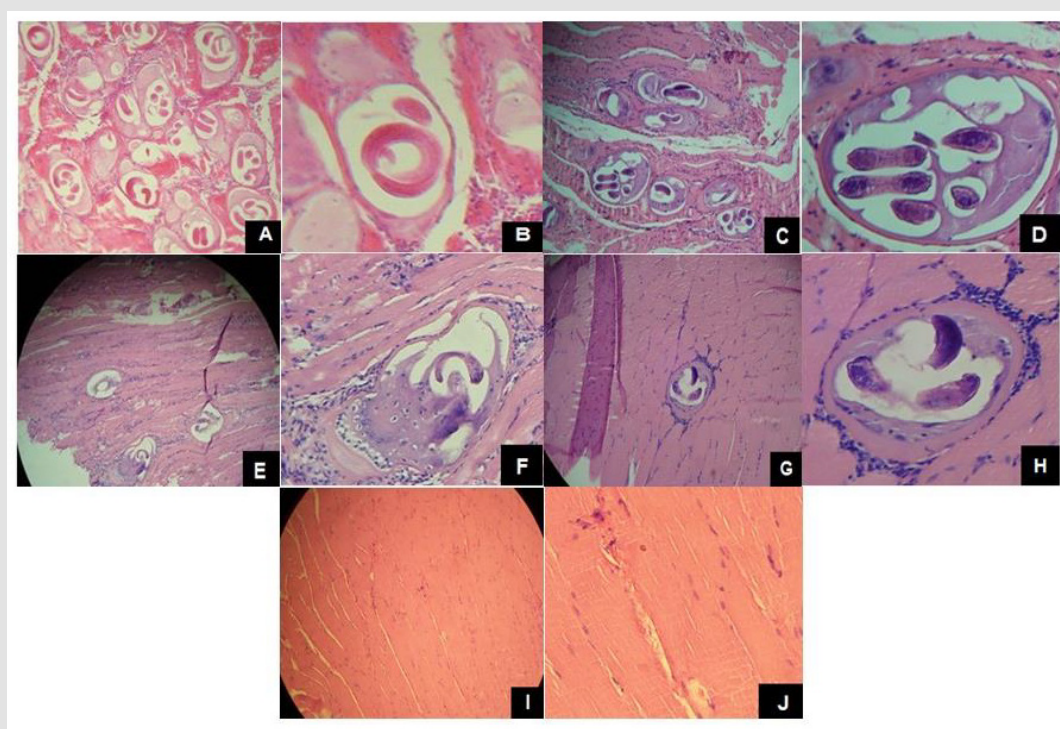

Figure 15: The Hematoxylin-Eosin Technique is shown, in A), B), C), D) the Trichinella spiralis implant observed under an optical light microscope in unimmunized animals, E) at sacrifice 30 days after immunization , F) at sacrifice 60 days after immunized, G) at sacrifice 90 days post immunized at 10X, H) at sacrifice 90 days post immunized at 40 X and I) and J) at 120 days where already The nurse cell of T.spiralis is not observed, post immunization. Material obtained in the Laboratory of Cell Biology and Microbiology UAZ. 


\section{Evaluation of the Soluble Antigen of T. Spiralis, VITS, Bacterial Vaccine and Lactobacillus Casei}

The administration of commercial Lactobacillus casei confers protection at the intestinal mucosa level in T. spiralis infection. Furthermore, based on the results obtained, administering a treatment in the early stages of the infection protects the host against infection by this parasite. The administration of an immunomodulator (VITS) and treatment with commercial Lactobacillus casei promotes a potentiated immune response by producing a greater degree of intestinal mucosa. Immunization with VITS in the experimental model prepares the organism to act against the parasite with a greater degree of effectiveness, thus observing an effective immune response against $T$. spiralis. An ANOVA statistical analysis was performed with the GraphPad Prism 6 program using the parasite loads obtained from the artificial digestion of each individual and with $95 \%$ confidence, resulting in that the groups treated with VITS, Bacterial Vaccine, Lactobacillus casei and soluble antigen of Trichinella spiralis compared to the infection control had a $\mathrm{P}<0.0001$.

\section{Epidemiological Studies}

From the sampling of 1096 sera from backyard and technical farm pigs from various municipalities of the state in 1998, an $8 \%$ incidence of Trichinellosis was found, the Dot ELISA technique for its diagnosis being reliable and affordable .A study was carried out in pigs in the municipal slaughterhouse of Zacatecas, Jerez, and Ojocaliente in 2006, where 85 samples were obtained from each of them, taking 15 grams of masseter which was analyzed by compression and artificial digestion, resulting in 2 positives. 51 languages of dogs collected in the Department of Pharmacology of the Academic Unit of Human Medicine and Health Sciences, of the UAZ, 3 (5.82\%) were positive with infection with T. spiralis, which allows defining that the parasite is found in domestic dogs, more often than you might think. In 2002.Analysis of 100 diaphragms of domestic rats and serum from the municipal garbage dump of Zacatecas. Diagnosis by direct techniques of compression and artificial digestion and indirect by MIDD, WB, Results: Trichinella spiralis was detected in 3 diaphragms of domestic rats by direct compression and artificial digestion technique, and by indirect MIDD and WB techniques. In 2006.A study was carried out on 3490 open population sera, of which 640 correspond to sera from children under 15 years of age and 2850 from adults, which were analyzed using MIDD techniques, presenting. In human sera from the Zacatecas Health Center, Zacatecas in 2006, 3 positives were detected by MIDD and WB with a predominance of the triplet of 42,45 and $48 \mathrm{kDa}$, From the 2008 Guadalupe Zacatecas Health Center, 12 were positive by MIDD, Dot-ELISA and IET techniques with a predominance of the 42,45 and $48 \mathrm{kDa}$ triplet, examining 1209 human serum samples.
In human sera from the open child population of the Calera Zacatecas Health Center, from 2011, 3 positives were detected by MIDD techniques, and 12 by Dot-ELISA and IET with a predominance of the triplet of 42,45 and $48 \mathrm{kDa}$. Ninety-two sera were collected, which were evaluated using the indirect techniques of MIDD, DotELISA and WB, from a technical high school in Fresnillo and 2 were positive by the three techniques in 2017.

\section{Diagnostic Kit}

Diagnostic kit based on the Dot-ELISA technique for which a murine model infected with different parasite loads from five to 1500 infective larvae (IL) of T. spiralis was used. The Dot-ELISA technique shows sensitivity from the second week after infection with $T$. spiralis $I L$. When making modifications to this technique, a non-significant difference was observed compared to the standardized technique. The objective of making the Trichinellosis Diagnostic Kit in the field was met. Which decreased time and steps. The statistical analysis was carried out in the GraphPad Prism 6 program applying an ANOVA between the results obtained with the standardized technique and after making the modifications. Resulting a non-significant variation with a value of $\mathrm{P}=0.5382$.

\section{Discussion}

The present study is an analysis of the work carried out in the Department of Cell Biology Microbiology of the UAZ, in the line of research of Trichinella spiralis, from 1986-2021. Which has allowed to carry out research work, teaching, training of undergraduate and postgraduate human resources, 80 theses, which have contributed results to the study of Trichinella spiralis., In implementation of experimental models, characterization of the life cycle of $T$. spiralis, establishment of direct and indirect techniques, evaluation of treatment with drugs and immunogens, epidemiological studies for the detection of the parasite and the proposal of a low-cost and accessible diagnostic kit for the field. Our results coincide with other authors, the investigations have been published. For us it is very important to continue with this line of research, because unfortunately the infection in many cases is not diagnostic, hence our interest in having effective treatments, diagnostic techniques that are preventive against this zoonosis that is increasingly distributed worldwide. climate change favors their presence, the loss of ecosystems, and all this contributes to diminishing and impacting the quality of life not only of humans but also of animals and ecosystems.

\section{Conclusions}

The Autonomous University of Zacatecas has a research line in Trichinella spiralis, which has allowed to carry substantive functions, including teaching, research, extension, dissemination, and having an impact on the training of human resources. The findings reported in this research include: a reproducible experimental 
model for the study of Trichinellosis, reliable diagnostic techniques and confirmatory $\mathrm{WB}$, an effective treatment using albendazole (which must be used under medical prescription), and the study of products such as the bacterial vaccine, the VITS immodulator, the Lactobacillus casei strain, which decrease the parasite load as well as the immunogen of the total soluble antigen of Trichinella spiralis. The contribution of this study has been to provide deeper insights in a disease which is present in the state of Zacatecas, Mexico and is commonly not properly diagnosed or confused with other diseases, we consider very important to continue promoting having a proper diagnosis and prevention of the disease.

\section{Conflict of Interest}

No conflict of interest with any institution/organization.

\section{References}

1. Olvera G (1896) Triquinosis en México contribución de dos casos para la historia en la capital de México. Gaceta Médica de México 33: 167.

2. Mazzotti L, Chavira C (1943) investigación en triquina en 600 diafragmas humanos de la ciudad de México. Rev Inv Salud Enf Tropicales 4: 343352.

3. Hernández López J (2016) Situación epidemiológica de la triquinosis. Boletín Epidemiológico. Sistema nacional de vigilancia epidemiológica. Número 47 (33): 3-11.

4. (2020) INEGI. Panorama sociodemográfico de Zacatecas Censo de Población y Vivienda 2020. 2021.

5. Cabral Soto, Villicaña Fuentes, Fragoso Uribe, Contreras Perfil Epidemiológico de la Triquinosis en el Estado de Zacatecas. Revista de Salud Pública Méx 32: 575-582.

6. http://www.ibt.unam.mx/computo/pdfs/bioterio.NOM-062

7. Chávez Guajardo EG, Saldivar Elías S, Muñoz Escobedo JJ, Moreno García MA (2006) Epidemiología una zoonosis vigente. Revista Electrónica de Veterinaria. REDVET $^{\oplus}: 1-19$.

8. Del Río A, Herrera DR (1984) Primer hallazgo de T. spiralis en diafragma de cadáver en Zacatecas. Nota previa. Salud pública de México 26: 596.

9. Del Río A, Herrera RM, Herrera R (1986) triquinosis experimental extracción de antígenos y procedimientos para detectar Anticuerpos. Archivo de investigación Médica 17: 359-567.

10. NOM-062-ZOO-1999.2001. Especificaciones técnicas para la producción, cuidado y uso de los animales de laboratorio. Ciudad de México: Diario Oficial de la Federación.

11. Moreno García MA, Maldonado Tapia Claudia H, García Mayorga EA, Reveles Hernández RG, Muñoz Escobedo JJ (2009) Fase intestinal de Trichinella spiralis en modelo murino. Acta Biológica Colombiana 14(1): 203-210.

12. Moreno García MA (2018) Epidemiología, diagnóstico y tratamiento de la Trichinellosis en México. 2018. Editorial Académica Española: 10-24.

13. Muñoz Escobedo J, Rivas GJ, Reveles Hernández RG, Reveles HM Berumen DTV, et al. (2004) Huéspedes que permiten la permanencia de Trichinella spiralis en el Estado de Zacatecas. REDVET 11: 1-9.

14. Moreno García MA, Rivas Gutiérrez, Jesús Berumen De La Torre, Vicente; Muñoz Escobedo Jesús (2007) Detección de Trichinella spiralis en Rata Doméstica del Basurero Municipal de Zacatecas REDVET. Revista Electrónica de Veterinaria 8(5): 1-8
15. Reveles HRG, Villalobos R, Saldivar S, Moreno MA (1997) implante histológico de Trichinella spiralis experimental. Parasitología al Día: 114- 118

16. Armed Forces, Institute of Pathology (1957) Manual of Histologic and Special Staining Techniques. Washington, D.C.: Armed Forces, Institute of Pathology 7: 1-36.

17. Bachman GW (1928) A pricipitine test in experimental trichiniasis. J Prev Med 2: 35.

18. Bradford MM (1976) A rapid and sensitive method for the quantitation of microgram quantities of protein utilizing the principle of protein dye binding, Anal biochem 72: 248-254.

19. Laemmil u K (1970) Cleavage of structural proteins during the assembly of the head of bacteriophage t4. Nature (London) 227: 680-685.

20. Nöckler K, Reckinger S, Broglia A, Mayer-Scholl A y Bahn PP (2002) Evaluation of a Western Blot and ELISA for the detection of antiTrichinella-IgG in pig sera. Veterinary Parasitology 163 (4): 341-347.

21. Ouchterlony O (1958) Diffusion in Gel Methods for Immunological Analysis in: Progress Allergy. Vol. V. Ed. Gallio P Basel, New York, Krager, New York, USA: 1-78.

22. Silva M, Vargas D, Vegaff, Sepúlveda R (1997)Técnicas inmunoenzimáticas en el diagnóstico de la Trichinellosis porcina. Parasitol al día 21: 25-30.

23. Towbin HT, Y sthanlin t. Gordon (1979) Electrophoretic transfer of proteins from polyacrilamide gels to nitrocelulosa sheets, procedure and some application. Proct Nathl Acado sci USA 76: 4350-4354.

24. Chávez Ruvalcaba I, Reveles Hernández RG, Saldívar Elías S, Muñoz Escobedo J, Morales Vallarta M, et al. (2006) Evaluation of 3 antiparasites on intestinal and muscular phase infection of Trichinella spiralis in the pig model. Revista Electrónica de Veterinaria REDVET ${ }^{\circledR} 7(6):$ 1-8.

25. García Robles MJ, Muñoz Escobedo JJ, Moreno García MA y Reveles Hernández G (2012) Utilidad del albendazol/quinfamida en el tratamiento de la fase intestinal de la infección por Trichinella spiralis en modelo murino. Archivos venezolanos de farmacología y terapéutica 31(3): 51-61.

26. Moreno Garcia MA, Vacio de la TMR, Reveles HRG, Muños EJJ (2001) Epidemiología de T. spiralis en el Estado de Zacatecas, México. Jornal Brasileiro de parasitología 37(4): 57.

27. Chávez Guajardo E, Morales Vallarta M, Saldivar Elías S, Reveles Hernández G, Muñoz Escobedo JJ, et al. (2010) Efecto del Albendazol en ratas Long Evans gestantes e infectadas con T. spiralis. Archivos Venezolanos de Farmacología y Terapéutica 29(4): 60-65.

28. Chávez Ruvalcaba F, Chavez Ruvalcaba MI, Hernández Luna CE, Muñoz Escobedo JJ, Muñoz Carrillo JL, et al. (2017) Evaluation of anti-Trichinella spiralis obtained by sublingual and conventional immunizations with the $45 \mathrm{kDa}$ protein. Acta Biológica Colombiana 22(2): 149-156.

29. Laredo SVT, Martínez L, Reveles HRG, Muñoz EJJ, Moreno GMA (2012) Modificación de la célula nodriza de Trichinella spiralis en ratas Long Evans inmunizadas con antígeno soluble total de Trichinella spiralis y sacrificadas en diferentes tiempos. Revista Ibero-latinoamericana de parasitología 71 (2): 160-166.

30. Maldonado Tapia CH, Reveles Hernández RG, Saldívar Elías S, Muñoz Escobedo JJ, Morales Vallarta M, et al. (2007) Evaluación del efecto protector de 2 inmunógenos de Trichinella spiralis en ratas Long Evans con modificación nutricional e infectado con Trichinella spiralis. Archivos Venezolanos de Farmacología y Terapéutica 26(2): 110-114.

31. Reveles, Hernández G, Muñoz Escobedo JJ, Saldívar Elías S, Moreno García MA (2000) Efecto del antígeno soluble total sobre larvas infectantes (LI) de T. spiralis implantadas en músculo estriado en modelo experimental. Revista Investigación Científica 2(2): 51-57. 
32. Silbestein DS, Despommier DD (1984) Antigens from Trichinella spiralis that induce a protective response in the mouse. J Immunol 132: 898

33. Berumen De La T Vicente, Muñoz E Jesús, Moreno G Alejandra (2002) Trichinellosis en perros callejeros de la ciudad de Zacatecas. México. Parasitología Latino Americana 57(1-2): 72-74.

34. Moreno G MA, Reveles HRG, Saldívar ESJ, Castañeda CV, Muñoz EJJ (2001) Evaluación del efecto de la temperatura en la viabilidad de T. spiralis en carne infectada de cerdo. Jornal Brasileiro de parasitología 37(4): 42.

35. Moreno García MA, Vacio de la Torre MR, Reveles Hernández RG, Román Díaz R, Berumen de la Torre V, et al. (2004) Estudio de la epidemiología,

ISSN: 2574-1241

DOI: 10.26717/BJSTR.2021.39.006322

Moreno García MA. Biomed J Sci \& Tech Res

(C) (P) This work is licensed under Creative

Submission Link: https://biomedres.us/submit-manuscript.php diagnóstico y tratamiento de la Trichinellosis en el estado de Zacatecas, México. Revista Virtual Visión Veterinaria 3(10): 1-24.

36. Del Río A, Herrera DR (1984) Primer hallazgo de T. spiralis en diafragma de cadáver en Zacatecas. Nota previa. Salud pública de México 26: 596.

37. Moreno GMA, Muñoz EJJ (1993) Características de la respuesta inmune en Trichinella spiralis. Investigación Científica 5(1): 17-28.

38. Alvarado RM, Meza LE, García ME, Saldívar S, Moreno GA (1996) Hormonal effect on the parasite load in the infection by T. spiralis of a murine experimental model. Trichinellosis. $9^{\text {th }}$ International Conference Trichinellosis (ICT9). Edit. Ortega P, Wakelin: 107-114.

$\begin{array}{ll}\text { BIOMEDICAL } & \text { Assets of Publishing with us } \\ \text { RESEARCHES } & \text { - Global archiving of articles } \\ \text { - Immediate, unrestricted online access }\end{array}$

